\title{
Knockout of Bbs 10 results in lack of cone electrical function and progressive retinal degeneration of rods and cones
}

Sara K. Mayer ${ }^{1,2}$, Jacintha Thomas ${ }^{2,}$ a , Megan Helms², b, Aishwarya Kothapalli,a, loana Cherascu $^{2}$, Adisa Salesevic ${ }^{2, ~ c}$, Elliot Stalter ${ }^{2}$, Kai Wang ${ }^{3}$, Poppy Datta², Charles Searby ${ }^{4}$, Seongjin Seo ${ }^{2}$, Ying $\mathrm{Hsu}^{2}$, Sajag Bhattarai ${ }^{2}$, Val C. Sheffield ${ }^{1,2,4}$, and Arlene V. $\operatorname{Drack}^{1,2,4 *}$

1. Interdisciplinary Graduate Program in Genetics, University of lowa

2. Department of Ophthalmology and Visual Sciences, Institute for Vision Research and Carver College of Medicine, University of lowa

3. Department of Biostatistics, University of lowa

4. Department of Pediatrics, University of lowa

${ }^{*}$ corresponding author

${ }^{a}$ current location: A.T. Still University, Kirksville College of Osteopathic Medicine, Kirksville, Missouri

${ }^{b}$ current location: University of Illinois - Chicago College of Medicine, Chicago, Illinois

${ }^{c}$ current location: University of lowa Department of Biology, lowa City, lowa 


\section{ABSTRACT}

Bardet Biedl Syndrome (BBS) is an autosomal recessive disorder caused by mutations in at least 22 different genes. A constant feature is early onset retinal degeneration leading to blindness, with variable central obesity, polydactyly, renal failure, and developmental anomalies. BBS type 10 (BBS10) is a common form caused by mutations in the BBS10 gene encoding a chaperonin-like protein. There are currently no treatments for the progressive vision loss. To aid in treatment development, a BBS10 mouse model was developed by knocking out the Bbs10 gene. Using optical coherence tomography (OCT), electroretinography (ERG), and a visually guided swim assay (VGSA), we demonstrate that $\mathrm{Bbs}^{-1 /}$ mice have progressive retinal degeneration. Cone electrical function was absent although cones were anatomically present on histology and retained partial function based on VGSA. The retinal outer nuclear layer (photoreceptor nuclei) progressively thinned as demonstrated on OCT and histology, and rod electrical activity decreased over time on ERG. These phenotypes are more rapidly progressive than retinal degeneration in the $B b s 1^{M 390 R / M 390 R}$ knock-in mouse. They are consistent with a cone-rod dystrophy distinct from typical rod-cone degeneration in retinitis pigmentosa and recapitulate aspects of retinal degeneration observed in humans with BBS10. This study has implications for BBS10 gene therapy. 


\section{Introduction}

Bardet Biedl Syndrome (BBS) is an autosomal recessive disorder caused by mutations in at least 21 different genes that are important for proper function of primary cilia (Mardy et al., 2021; Weihbrecht et al., 2017; Zhou et al., 2021). Although pleomorphic with kidney failure, obesity, developmental anomalies and diabetes, retinal degeneration occurs in all patients and may be an isolated feature (Forsythe and Beales, 2013; Green et al., 1989; Schachat and Maumenee, 1982). Retinal degeneration usually begins in the first decade of life, and results in rapidly deteriorating visual acuity, decreased visual field and eventually blindness (Green et al., 1989; Schachat and Maumenee, 1982). BBS type 10 (BBS10) is a common form caused by mutations in the BBS10 gene encoding a chaperonin-like protein which helps to assemble the BBsome, a complex of proteins responsible for ciliary transport (Singh et al., 2020; Stoetzel et al., 2006). BBS10 represents almost $25 \%$ of all BBS cases (Forsythe and Beales, 2013), making this subtype a high yield target for treatment. Recently it has been reported that the onset and progression of retinal degeneration is earlier and faster in patients with BBS10 compared to BBS1, another common subtype (Davis et al., 2007; Grudzinska Pechhacker et al., 2021). Research into BBS10 is important to determine points during the disease course where treatment interventions would be successful.

BBS mouse models for many of the causative genes have been created to better study the etiology and potential treatment of BBS-associated retinal degeneration (Bentley-Ford et al., 2021; Cognard et al., 2015; Davis et al., 2007; Hsu et al., 2017; Zhang et al., 2011). Each BBS mouse model reported has a similar retinal phenotype to that seen in human patients (Cognard et al., 2015; Datta et al., 2015; Davis et al., 2007; Nishimura et al., 2004; Zhang et al., 2011; Zhang et al., 2013). A previous study utilized a Cre/Lox system where the LoxP sites were directed around exon 2 of the Bbs 10 gene. A total knockout was created by breeding with a Cadh16-CreDeleter line. This study explored retinal phenotype at two months of age and found thinner retinal layers and decreased phototransduction function. However, a time course of the condition was not established, differences between rod and cone function were not explored, and functional vision was not examined (Cognard et al., 2015). Extensive characterization is necessary to assess treatment effect for translational studies. Here we report the retinal degeneration phenotype of the $B b s 10^{-/}$mouse based on anatomic studies using histology, optical coherence tomography (OCT), retinal electrophysiology utilizing electroretinograms (ERG), and functional vision based on a visually guided swim assay (VGSA). The VGSA is designed to mimic the human multiluminance mobility test (MLMT) (Laird et al., 2019; Pang et 
al., 2008; Pang et al., 2006; Prusky et al., 2000; Sarria et al., 2015) utilized as a functional endpoint in human retinal gene therapy clinical trials. In the $B b s 10^{--}$mouse, cone electrical activity is absent from the earliest age tested, while rod function is present though lower than normal levels and diminishes further over time. This differs from most types of retinitis pigmentosa, in which rod loss precedes cone loss. The mouse recapitulates the cone retinal phenotype reported in BBS10 patients (Grudzinska Pechhacker et al., 2021). A functional assay of cone vision, the light adapted VGSA, demonstrated that visually guided navigation is possible even with very low cone electrical function. This has implications for the possibility of recovering useful vision, even in eyes with few remaining photoreceptors.

\section{Results}

\section{Deletion of the mouse Bbs10 gene}

$B b s 10^{-/}$mice were developed using an embryonic stem cell line from the KOMP repository (KOMP ES cell line Bbs10tm1(KOMP)VIcg \#052679-UCD). Bbs10 transcripts are detected in whole eyes of one month old Bbs $10^{+/-}$mice, but not in eyes of $B b s 10^{-/}$mice (Fig S1). Mouse $B b s 10$ is composed of two exons and both exons are deleted in this line, removing the entire protein coding region of the Bbs10 gene. As a result, Bbs $10^{-/-}$mice do not make any Bbs 10 mRNA or protein (Fig. S1). Bbs10\% males are sterile, but females are fertile, as in other BBS mice models (Cognard et al., 2015; Datta et al., 2015; Davis et al., 2007; Nishimura et al., 2004; Zhang et al., 2011; Zhang et al., 2013). Therefore, all mice must be produced with $B b s 10^{+/} /$ $\mathrm{Bbs} 10^{+/-}$or $\mathrm{Bbs} 10^{+/-} / \mathrm{Bbs} 10^{-/}$pairings using only heterozygous males and either heterozygous or knockout females. All mice were genotyped prior to experimentation and analysis. Genotyping data display a clear single 260-bp PCR product in knockout pups compared to a 445-bp PCR product in heterozygous and wildtype (WT) pups (Fig. S2). Only homozygous knockout mice display a retinal phenotype, therefore, control mice consisted of $\mathrm{Bbs}^{+0^{+/}}$and $\mathrm{Bbs}^{\mathrm{H}} \mathrm{O}^{+-}$ littermates.

\section{$\mathrm{Bbs10}^{-/}$mice are smaller at birth and become progressively larger than unaffected controls}

$B b s 10^{-/}$mice were smaller than WT and heterozygous $B b s 10^{+/-}$littermates at 1 month of age.

(Fig 1a). At age postnatal (P) day $19-21$, WT pups averaged $11.11 \mathrm{~g}( \pm 1.68 \mathrm{~g}$ Standard Deviation (SD)) $(n=11)$ while knockout pups averaged $6.44 \mathrm{~g}( \pm 1.45 \mathrm{~g}$ SD) $(\mathrm{n}=7)$. By 4 months of age the average weight of control mice was $27.43 \mathrm{~g}( \pm 4.20 \mathrm{~g}$ SD) $(n=12)$, while average for knockout was $36.73 g$ ( $\pm 3.35 g$ SD) $(n=3)$ (Fig. 1) and this difference persisted throughout life. Knockout pups 
had increased mortality. Special husbandry that included feeding nursing mothers and their pups Diet Gel (ClearH $\mathrm{H}_{2} \mathrm{O}$, Westbrook, ME) and delayed weaning up to P35 for survival of affected pups to adulthood. Thus, Bbs $10^{-/}$knock-out mice display weight abnormalities similar to individuals with BBS10 and required extra care to prevent mortality.

\section{$\mathrm{Bbs} \mathrm{10}^{--}$mice had progressive loss of retinal outer nuclear layer thickness.}

Optical Coherence Tomography (OCT) is a non-invasive imaging technique that can be used to observe the retinal layers in vivo (Fischer et al., 2009). The thickness of the outer nuclear layer $(\mathrm{ONL})$ of the retina is a common indicator of retinal degeneration, as it contains the nuclei of rod and cone photoreceptors (Lujan et al., 2015). Loss of ONL thickness indicates a decrease in the number of photoreceptors and is associated with retinal degeneration (Fig. 2a brackets). At one month of age, the control mice had an average ONL thickness of $0.055 \mu \mathrm{m}( \pm 0.002 \mu \mathrm{m}$ Standard Error of the Mean (SEM)) compared to $0.047 \mu \mathrm{m}\left( \pm 0.001 \mu \mathrm{m}\right.$ SEM) for $B b s 10^{-/-}$mice, which is $85 \%$ of control. The thickness of the ONL for control mice remained between $0.05 \mu \mathrm{m}$ and $0.055 \mu \mathrm{m}$ from one month to 8 months of age. In contrast, the $B b s 10^{-/}$mice had progressive loss of ONL thickness each month of life. By three months of age, the average thickness of the $B b s 10^{-/-}$mouse ONL was $0.028 \mu \mathrm{m}( \pm 0.001 \mu \mathrm{m}$ SEM) compared to $0.054 \mu \mathrm{m}( \pm 0.001 \mu \mathrm{m})$ of control mice. This is roughly $50 \%$ thickness of that of control mice. By seven months of age, $B b s 10^{-/}$mice had no distinguishable ONL on OCT (Fig. 2b). In fact, histological analysis

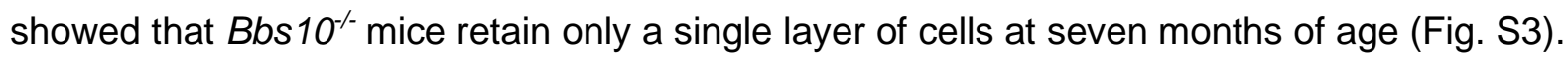
Thus, OCT was able to show that $B b s 10^{-/}$mice have a significant loss of ONL over the course of their life.

\section{Young $\mathrm{Bbs10}^{-/}$mice display abnormal retinal organization and lack photoreceptor cell markers}

$B b s 10^{-/}$mice have abnormal photoreceptor outer segments as early as P15 shown by Transmission Electron Microscopy (TEM) (Fig. 3). By contrast, control mice exhibited organized outer segment discs of the photoreceptors. These outer segments have horizontally organized discs present in the region of the EM photo indicated by the yellow arrow. In contrast, Bbs $10^{-/}$ mice lack this disc organization as well as have a lack of polarity organization in any remnant of an outer segment. This demonstrates the outer segments of the photoreceptors were anatomically abnormal in $\mathrm{Bbs}^{-/-}$mice. This early abnormality has implications for the role of BBS10 in early development of the retina and makes early treatment of BBS10 in humans 
required rather than optional to target prevention and progressive degeneration of photoreceptors.

Immunofluorescence images of the retina of P21 mice reveal mislocalized and absent cone markers. OPN1MW, which is the protein pigment for Medium-wave-sensitive opsin 1, is a cone photoreceptor pigment (Deeb, 2004). It was easily detected in young P21 Bbs10 mice, although it was mislocalized to inner segments. This is displayed in the upper panels of figure 4. Normal localization of OPN1MW would be confined to outer segments, as seen in the control mouse retina (Datta et al., 2015). However, the cone specific protein, GNAT2, which is the alpha subunit of cone transducin (Aligianis, 2002), was almost entirely absent from $\mathrm{Bbs}^{-/} \mathrm{O}^{-}$ mouse photoreceptor layers by P21 (Fig. 4). In previous studies of mouse BBS model, it was found that GNAT2 was highly mislocalized to the inner segment, as is the case here with OPN1MW (Datta et al., 2015). A lack of properly localized outer segments and cone specific proteins at such an early age indicate that the BBS10 disease phenotype is present very early in life.

\section{Young $\mathrm{Bbs}^{-/-}$mice display decreased electroretinogram amplitudes and lack a $5 \mathrm{~Hz}$ flicker response}

The electroretinogram (ERG) is used to measure the entire electrical output of the photoreceptors of the retina (ref). The ERG uses a series of light flashes of different intensities in different lighting conditions to elicit separate responses from rods and cones in the retina. When dark-adapted, rods are the predominant photoreceptor that fires in response to a dim light stimulus (Robson et al., 2018). However, when light adapted, cones predominantly respond. Using a modified International Society for Clinical Electrophysiology of Vision (ISCEV) standard protocol (Mcculloch et al., 2015), four conditions were tested. Dark adapted retinas were stimulated with $0.01 \mathrm{~cd} \cdot \mathrm{s} / \mathrm{m}^{2} \mathrm{dim}$ flashes, to which only rods respond, followed by $3.0 \mathrm{~cd} \cdot \mathrm{s} / \mathrm{m}^{2}$ bright flashes which elicit responses from both rods and cones (Fig. $5 a$ and b)(Robson et al., 2018). The $3.0 \mathrm{~cd} \cdot \mathrm{s} / \mathrm{m}^{2}$ flash is called the standard combined response (SCR) because it represents a combination of rod and cone responses. The SCR causes the largest number of photoreceptors to fire of all conditions tested and was therefore the largest response (Fig. 5b). Light-adapted conditions test cone responses and included light adapted $3.0 \mathrm{~cd} \bullet \mathrm{s} / \mathrm{m}^{2}$ single flashes and a $5 \mathrm{~Hz}$ flicker (Fig. $5 \mathrm{c}$ and d). The $5 \mathrm{~Hz}$ flicker is used the same $3.0 \mathrm{~cd} \cdot \mathrm{s} / \mathrm{m}^{2} \mathrm{flash}$, but at a high frequency of $5 \mathrm{~Hz}$. Cones recover faster than rods from previous light flashes (Tanimoto et al., 2015), so the $5 \mathrm{~Hz}$ flicker elicits a response only from cones while it bleaches 
rods and prevents rod firing (Tanimoto et al., 2015). ERG a-waves and b-waves were analyzed for each condition; the a-waves represent primarily photoreceptor electrical firing while the bwave is generated primarily by bipolar cells (Robson et al., 2018). Photoreceptors synapse and transmit the visual signal to the bipolar cells, thus the b-wave follows the a-wave (Robson et al., 2018).

Compared to control mice, the Bbs $10^{-/-}$mice show reduced SCR ERGs by P19. At one month of age the $\mathrm{Bbs}_{10} \mathrm{O}^{--}$mice are significantly different from control mice in the $0.01 \mathrm{dim}$ flash and the 3.0 SCR (Fig. $5 \mathrm{a}$ and b). The knockout mice lack a $5 \mathrm{~Hz}$ flicker response at this age with electrical activity of the retina indistinguishable from background signal (Fig. $5 d$ ). Interestingly, while the $\mathrm{Bbs}_{10^{-/}}$mice lack a recordable ERG cone response at a young age (Fig. $5 \mathrm{c}$ and d), cones are anatomically present on histology at P21 (Fig. 4). The Bbs $10^{-/}$mice display drastically different b-waves in the light adapted 3.0 bright flash condition. This condition became non-recordable at five months of age (Fig. 5c). The $5 \mathrm{~Hz}$ flicker was not graphed due to the non-recordable nature at the earliest ages tested (Fig. 5d). The ERG data indicate that the $\mathrm{Bbs}_{10} \mathrm{C}^{-}$mice have severe phototransduction deficiencies at an early age that become worse as they age.

\section{Bbs 10/- mice have decreased functional vision compared to controls}

An ERG is a test of functional photoreceptors but not a test of functional vision. It is possible to have a non-recordable ERG while retaining useful functional vision. We developed a visually guided swim assay (VGSA) to test functional vision of the $B b s 10^{-/}$mouse compared to control mice. This was done by random placement of a highly visible platform in a pool of water. The mice locate this platform via vision and swim to it. Swim time was measured as time to platform (TTP), which is shorter in mice with normal vision than in mice with retinal degeneration and reduced vision.

Analysis was performed on five affected $\mathrm{Bbs} 10^{-/-}$mice, and eight control unaffected mice including two unaffected $\mathrm{Bbs} \mathrm{O}^{+/-}$mice littermates and six WT SV129 mouse. The average TTP for control mice aged 6 months was 5.07s $( \pm 0.67 \mathrm{~s}$ SEM) in the light and $5.50 \mathrm{~s}( \pm 0.63 \mathrm{~s}$ SEM) in the dark. At the age of nine months, the average TTP for control mice was $3.33 \mathrm{~s}( \pm 0.39 \mathrm{~s}$ SEM) in the light and $4.34 \mathrm{~s}( \pm 0.82 \mathrm{~s}$ SEM $)$ in the dark. The averages were not significantly different when compared with each other, showing that functional vision remained stable in control mice as they age. These 
findings also show that the visually guided swim assay provided a reproducible measure of visual function in mice.

In contrast, the $\mathrm{Bbs}^{-/}$mice have an average TTP at age six months of $14.08 \mathrm{~s}( \pm 3.62 \mathrm{~s}$ SEM) while light-adapted and 20.97s ( \pm 0.68 s SEM) while dark adapted (Fig 6). In both conditions, it is significantly different from WT ( $p$-value $=0.0102$ and $p$-value $=<0.0001$ for light-adapted and darkadapted respectively). It is also notable that there is a trend toward a difference ( $p$-value=0.0982) between light and dark conditions for the $B b s 10^{-/}$mice at this age. While not significant, this suggests that $B b s 10^{-/}$mice have worse vision in the dark compared to the light at this young age. By the age of nine months, the Bbs $10^{-/-}$mice average a longer TTP of $31.40 \mathrm{~s}( \pm 3.94 \mathrm{~s} \mathrm{SEM})$ in the light and 35.99s $( \pm 2.57 \mathrm{~s}$ SEM) in the dark. This is different when compared to WT of the same age and in the same lighting conditions (3.33s and 4.34s respectively) $(p=<0.0001)$.

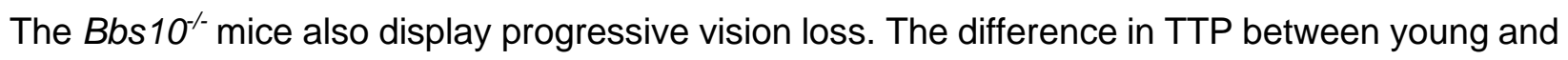
old $B b s 10^{--}$mice was significant for the light-adapted and dark-adapted conditions $(\mathrm{p}=0.0119$ and $p=0.0005$, respectively). The VGSA is more sensitive than ERG in detecting cone function. The initial ERG of the $5 \mathrm{~Hz}$ flicker showed that the cone response was already below the threshold of detection of the full field ERG, which is a mass response. This indicates that a small cohort of functioning cones were not detectable on ERG because their summed amplitude was not robust enough for detection, however this same small cohort of functional cones was adequate for essentially normal navigation in the swim assay in young mice. As the mice aged and the number of cones declined, the VGSA was able to detect a loss of function due to fewer photoreceptors, even though ERG waveform amplitudes were already indistinguishable from background signals.

\section{$B b s 10^{-/}$mice exhibit a more severe retinal degeneration than the $B b s 1^{\text {M390R/M390R }} \mathrm{BBS1}$ mouse model}

In humans, Bardet-Biedl Syndrome Type 1 (BBS1) has been shown to have a less severe disease progression than BBS10 (Grudzinska Pechhacker et al., 2021). Together, BBS1 and BBS10 account for about 50\% of all BBS cases (Grudzinska Pechhacker et al., 2021). A mouse model of the most common BBS1-causing mutation, homozygous M390R, was developed by our group previously (Davis et al., 2007) and was available for comparison to the BBS10 mouse model described here. For this comparison, both mouse models were crossed onto the 129/SvJ background for at least 7 generations. At six months of age, the $B b s 10^{-/-}$mice were compared to $B b s 1^{M 390 R / M 390 R}$ mice. Bbs10\%- mice completely lack the ONL at six months of age. By contrast 
the $B b s 1^{M 390 R / M 390 R}$ retain a thin but present layer on OCT images at six months of age. ERGs

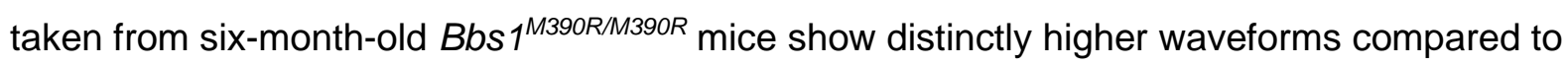
waveforms from $\mathrm{Bbs}_{10} 0^{--}$mice. Of note, a robust $5 \mathrm{~Hz}$ flicker response is present in young

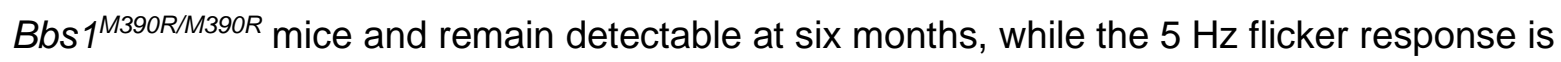
absent from $\mathrm{Bbs}_{10}^{-/}$mice even at a young age (Fig. 5d and Fig. 7b). Functional vision of $B b s 1^{\text {M390R/M390R }}$ mice is also better at six months of age than age-matched $B b s 10^{-/}$mice. In light adapted and dark adapted conditions, results demonstrate that the mouse models recapitulate the humans diseases, with BBS10 being more severe than BBS1.

\section{Discussion}

This study sought to characterize the retinal phenotype in a new mouse model of BBS10, one of the most common types of BBS in humans (Grudzinska Pechhacker et al., 2021; Stoetzel et al., 2006). The mice display a characteristic progressive retinal degeneration that is anatomically and functionally distinguishable from unaffected control mice, as well as from a BBS1 mouse model.

The lack of response in the cone ERG could be a result of loss of functional cone transducin, needed for transmitting signals from cone photoreceptors (Aligianis, 2002), or the amplitude of the electrical signal may be lower than the threshold of detection on ERG. This could be due to either low numbers of cones firing or low amplitude of the electrical impulse from individual cones. Our discovery of disordered outer segments and lack of GNAT2 protein at early ages

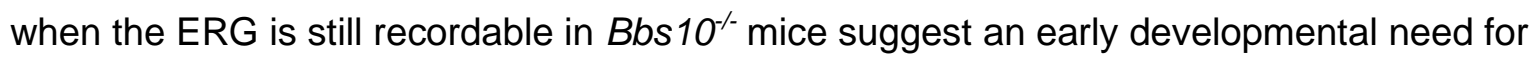
Bbs10 protein in photoreceptor formation as well as maintenance. It is known that levels of BBS proteins start to increase around P4-6 and peak at P15 when the outer segment begins to mature (Hsu et al., 2017). The levels of proteins begin to decrease after P15 to maintenance levels (Hsu et al., 2017). The abnormal anatomical phenotype in the $B b s 10^{-/-}$mice suggests Bbs10 is also important during this early development period. It can be speculated that the reason for the mislocalization of OPN1MW and complete lack of GNAT2 is a result of BBSome malfunction at P15. It is possible that at P15, OPN1MW needs the functional BBSome for transport into the outer segment. GNAT2 is a protein that forms a complex with two other subunits to produce a full functional protein, cone transducin (Aligianis, 2002). It may need BBS10 to fold properly and bind with its partners. Without BBS10 to direct formation of a 
functional BBSome, cone transducin cannot form in these early stages of eye development and is therefore completely absent at in photoreceptors at P21.

$\mathrm{Bbs}_{10}$ - mice perform the VGSA at six months with faster TTP times in bright light than in dark light, averaging much closer TTP to control mice in the light than in the dark. This indicates that functional vision in bright light, remains present early in life, despite the lack of GNAT2 in cones and lack of a $5 \mathrm{~Hz}$ cone response on ERG. Because the ERG is a mass retinal response and there are far more rods than cones in the mouse retina (Fu and Yau, 2007), a reduction in rod numbers may result in a diminished ERG amplitude, while a proportional reduction in cone numbers may result in an electrical output too small for our current technology to record. Our data suggests that very few functional cones are needed to enable useful vision in the light. This is promising for treatments such as gene therapy because it suggests that reactivating or rescuing even a small number of cones in humans with BBS10 would confer a large functional benefit.

Although mutations in BBS disease genes generally cause syndromic retinal degeneration, isolated retinitis pigmentosa $(\mathrm{RP})$ has been reported with mutations in BBS1 (Estrada-Cuzcano et al., 2012a; Estrada-Cuzcano et al., 2012b) and BBS10 (Grudzinska Pechhacker et al., 2021). The retinal phenotype of BBS1 is typically described as retinitis pigmentosa-like rod-cone dystrophy (Grudzinska Pechhacker et al., 2021); however, BBS10 may occur as a cone-rod dystrophy, or even an isolated cone dystrophy (Grudzinska Pechhacker et al., 2021). Patients with BBS10 may present with simultaneous night blindness and peripheral field constriction, as well as reduced central vision, a devastating combination (Grudzinska Pechhacker et al., 2021). $\mathrm{Bbs}_{10} \mathrm{~T}^{-/}$mice demonstrate a similar phenotype making them an excellent avatar for preclinical treatment trials. It is worth noting that the mouse models used in this paper are not both knockouts. The BBS10 mouse model is a full knockout that produces no Bbs10 mRNA while the BBS1 mouse model is a substitution mutation changing just one amino acid in the protein. This may contribute to the difference in severity seen between the mouse models. However, this is an accurate comparison of the two diseases for humans. The most common cause of BBS10 in humans is a single nucleotide insertion that results in premature termination and loss of protein expression (Stoetzel et al., 2006), while the most common cause of BBS1 is this same amino acid substation mutation reported in the mouse model here (Davis et al., 2007; Mykytyn et al., 2002). This substitution mutation may leave some part of a functioning protein, albeit abnormal while the BBS10 mutation lacks any protein whatsoever. Thus, a partially functional BBS1 gene 
may result in a partially functional BBSome, while a completely nonfunctional BBS10 gene may lead to little or no BBSome formation, explaining the more severe BBS10 retinal phenotype in mouse and man.

In conclusion, a knockout mouse model of BBS10 recapitulates the human retinal degeneration and shares features of the human condition. Comparison to a model of BBS1 demonstrates that different subtypes of BBS will likely require different rescue strategies and timing of treatment. Rods and cones are present early in life in $B b s 10^{-/}$mice retinas but are abnormal and progressively degenerate over time. The early non-recordable $5 \mathrm{~Hz}$ flicker ERG offers a robust endpoint for therapeutic rescue studies. Maintaining useful functional vision in the light even when ERGs are nonrecordable suggests that rescuing even a small percentage of cones could provide useful visual improvement to patients.

\section{Materials and Methods}

Animals: Experiments were approved by the Institutional Animal Care and Use Committee (IACUC) at the University of lowa and conducted following the recommendations in the Guide for the Care and Use of Laboratory Animals of the National Institutes of Health. Mice were maintained on a standard 12/12 hour light/dark cycle with food and water provided ad libitum. The breeders to start the line contained the Rd8 mutation in Crb1; this was bred out early in the process. Genetic testing confirmed WT for the Crb1 gene as well as genotyping for the knockout mutation. Wild type 129/SvJ mice were obtained from Jackson Laboratory, Bar Harbor, Maine.

Optical Coherence Tomography: OCTs were performed using the Bioptigen OCT with a small rodent lens (Research Triangle Park, NC) as previously described(Drack et al., 2012). Mice were anesthetized with a mixture of ketamine $(87.5 \mathrm{mg} / \mathrm{kg})$ and xylazine $(2.5 \mathrm{mg} / \mathrm{kg})$ and pupils were dilated with tropicamide 1\%. Measurements were taken of the outer nuclear layer as measured from $3 \mu \mathrm{m}$ on either side of the optic nerve on all images. The measurements were done using the in-software calipers provided by Bioptigen.

Microscopic anatomy: Mice were sacrificed at times indicated. Retinal sections were stained with rabbit anti-OPN1MW polyclonal antibody (EMD Millipore AB5405) and rabbit anti-GNAT2 polyclonal antibody (Abcam ab97501). Methods to perform immunofluorescence stainings are 
as previously described (Datta et al., 2021; Datta et al., 2019; Datta et al., 2020). Transmission electron microscopy was performed as described previously (Hsu et al., 2017).

Electroretinograms: Full-field electroretinograms (ERGs) were conducted within 2 weeks of each swim assay. Full-field ERG was performed using the Celeris Diagnosys system (Diagnosys LLC, Lowell, MA). The mice were dark adapted overnight before ERG was conducted. Mice were anesthetized with a mixture of ketamine $(87.5 \mathrm{mg} / \mathrm{kg})$ and xylazine $(2.5$ $\mathrm{mg} / \mathrm{kg}$ ). The mice received $0.1 \mathrm{~mL}$ of the mixture per $20 \mathrm{~g}$ body weight. ERGs were recorded simultaneously from the corneal surface of each eye after the pupils were dilated with $1 \%$ tropicamide, using Diagnosys Celeris touch stimulator electrodes. Gonak gel (Akorn, Inc., Lake Forest, IL) was place on the cornea of each eye before the electrode was positioned. Light flashes were produces by the touch stimulator electrodes. Dim red light was used for room illumination until dark-adapted testing was completed. A modified International Society for Clinical Electrophysiology of Vision (ISCEV) protocol was used. A dim flash measured at 0.01 $\mathrm{cd} \cdot \mathrm{s} / \mathrm{m}^{2}$ is performed first to measure rods, followed by a bright flash at $3.0 \mathrm{~cd} \mathrm{~s} \mathrm{m-2} \mathrm{to} \mathrm{measure}$ the standard combined response (SCR) of the rods and cones. Mice are then light adapted for 10 minutes, after which they are tested with a bright flash at $3.0 \mathrm{~cd} \cdot \mathrm{s} / \mathrm{m}^{2}$ followed by a flicker of $5 \mathrm{~Hz} .15$ sweeps are taken of each condition except the $5 \mathrm{~Hz}$ flicker, in which 20 sweeps are taken. ERG results are analyzed following data collection using the Diagnosys software to eliminate sweeps that show interference such as mouse movements or ambient electric signal. If more than 5 sweeps needed to be eliminated, the test was null and was repeated for cleaner results. The light adapted protocol tests cones, especially in the case of the $5 \mathrm{~Hz}$ flicker which only elicits a response from cones in mice(Tanimoto et al., 2015).

Visually Guided Swim Assay: A modified Morris water maze (Morris, 1984) incorporating some features of the mouse swim assay developed by Pang et al. (Pang et al., 2008) was utilized to test functional vision. A plastic swimming pool was used for swimming. The pool diameter measures 35 inches at the bottom, 38 inches at the 4-inch water level, and 39 inches at the top. A 3" diameter pvc tube with rubber caps on both ends was used as a platform for the mice to climb onto to end the trial. The platform was the same on both ends, so it could be flipped between trials to mitigate any odor that might aid in platform localization. A "flag", consisting of a small paper American flag taped to a wooden stick was attached to the side of the platform to make it more visible to the mice. Platform location consisted of 8 equally spaced 
pre-set locations. The order of the locations of the platforms was determined prior to the day's experiment and was randomly determined each day.

Swim protocol consists of 4 light adapted training days followed by 4 light adapted testing days. Following light adapted testing, 2 days of dark adapted training and then 4 days of dark-adapted testing are performed. Light adaptation was performed in a brightly lit room of typical fluorescent ceiling lights. Dark adaptation was performed in the same room with the lights off and dim red lights to assist the observers to see the experiments. An infrared lamp was aimed at the pool and the location of the mice was determined by night vision goggles.

Each testing day of swimming, mice performed 5 swim trials to 5 different randomly selected platform locations. These platforms were the same for all mice in the testing group. A limit of 60 seconds was set for swim TTPs to prevent mice from becoming fatigued; if the platform was not attained by 60 seconds, the mouse was gently removed from the pool, and the time to platform for that particular trial was recorded to be 60 seconds.

Genotyping: Genotyping was performed using mouse tail snips collected at P14. DNA was extracted and Bbs10 was amplified using wildtype and knockout forward primers and the same reverse primer (Supplementary materials).

RT-PCR: RNA was extracted from whole eye lysates and amplified up using SuperScript VILO Master Mix to create a cDNA library. After this, PCR was run on the cDNA amplified by primers indicated (Supplementary materials). Actin was used as a control.

Statistical Analysis: Statistical analysis and figure creation was done using GraphPad Prism. Comparisons between age group means was done using a Sidak's multiple comparison's test for ERG, OCT and weight data. Bbs $10^{-/-}$mice were compared to littermate controls for all experiments. Graphs for weight data and OCT were plotted using mean and standard deviation. Graphs for ERG was plotted using the mean and standard error of the mean (SEM). Comparison $\mathrm{p}$-values between TTP in the swim assay were calculated using a Student's T-test. All trial swim times were used to calculate the $p$-values and figures were made using the mean and SEM. All analyses were performed using an alpha value of 0.05 . 
References:

Aligianis, I. A. (2002). Mapping of a novel locus for achromatopsia (ACHM4) to 1p and identification of a germline mutation in the alpha subunit of cone transducin (GNAT2). Journal of Medical Genetics 39, 656-660.

Bentley-Ford, M. R., Engle, S. E., Clearman, K. R., Haycraft, C. J., Andersen, R. S., Croyle, M. J., Rains, A. B., Berbari, N. F. and Yoder, B. K. (2021). A mouse model of BBS identifies developmental and homeostatic effects of BBS5 mutation and identifies novel pituitary abnormalities. Human Molecular Genetics 30, 234-246.

Cognard, N., Scerbo, M. J., Obringer, C., Yu, X., Costa, F., Haser, E., Le, D., Stoetzel, C., Roux, M. J., Moulin, B., et al. (2015). Comparing the Bbs10 complete knockout phenotype with a specific renal epithelial knockout one highlights the link between renal defects and systemic inactivation in mice. Cilia 4.

Datta, P., Allamargot, C., Hudson, J. S., Andersen, E. K., Bhattarai, S., Drack, A. V., Sheffield, V. C. and Seo, S. (2015). Accumulation of non-outer segment proteins in the outer segment underlies photoreceptor degeneration in Bardet-Biedl syndrome.

Proceedings of the National Academy of Sciences 112, E4400-E4409.

Datta, P., Cribbs, J. T. and Seo, S. (2021). Differential requirement of NPHP1 for compartmentalized protein localization during photoreceptor outer segment development and maintenance. PLOS ONE 16, e0246358.

Datta, P., Hendrickson, B., Brendalen, S., Ruffcorn, A. and Seo, S. (2019). The myosin-tail homology domain of centrosomal protein 290 is essential for protein confinement between the inner and outer segments in photoreceptors. Journal of Biological Chemistry 294, 19119-19136.

Datta, P., Ruffcorn, A. and Seo, S. (2020). Limited time window for retinal gene therapy in a preclinical model of ciliopathy. Human Molecular Genetics 29, 2337-2352.

Davis, R. E., Swiderski, R. E., Rahmouni, K., Nishimura, D. Y., Mullins, R. F., Agassandian, K., Philp, A. R., Searby, C. C., Andrews, M. P., Thompson, S., et al. (2007). A knockin mouse model of the Bardet Biedl syndrome 1 M390R mutation has cilia defects, ventriculomegaly, retinopathy, and obesity. Proceedings of the National Academy of Sciences 104, 19422-19427.

Deeb, S. S. (2004). Molecular genetics of color-vision deficiencies. Visual Neuroscience 21, 191-196.

Drack, A. V., Dumitrescu, A. V., Bhattarai, S., Gratie, D., Stone, E. M., Mullins, R. and Sheffield, V. C. (2012). TUDCA Slows Retinal Degeneration in Two Different Mouse Models of Retinitis Pigmentosa and Prevents Obesity in Bardet-Biedl Syndrome Type 1 Mice. Investigative Opthalmology \& Visual Science 53, 100.

Estrada-Cuzcano, A., Koenekoop, R. K., Senechal, A., De Baere, E. B. W., De Ravel, T., Banfi, S., Kohl, S., Ayuso, C., Sharon, D., Hoyng, C. B., et al. (2012a). BBS1 Mutations in a Wide Spectrum of Phenotypes Ranging From Nonsyndromic Retinitis Pigmentosa to Bardet-Biedl Syndrome. Archives of Ophthalmology 130, 1425.

Estrada-Cuzcano, A., Roepman, R., Cremers, F. P. M., Den Hollander, A. I. and Mans, D. A. (2012b). Non-syndromic retinal ciliopathies: translating gene discovery into therapy. Human Molecular Genetics 21, R111-R124.

Fischer, M. D., Huber, G., Beck, S. C., Tanimoto, N., Muehlfriedel, R., Fahl, E., Grimm, C., Wenzel, A., Remé, C. E., Van De Pavert, S. A., et al. (2009). Noninvasive, In Vivo 
Assessment of Mouse Retinal Structure Using Optical Coherence Tomography. PLoS ONE 4, e7507.

Forsythe, E. and Beales, P. L. (2013). Bardet-Biedl syndrome. European Journal of Human Genetics 21, 8-13.

Fu, Y. and Yau, K.-W. (2007). Phototransduction in mouse rods and cones. Pflügers Archiv European Journal of Physiology 454, 805-819.

Green, J. S., Parfrey, P. S., Harnett, J. D., Farid, N. R., Cramer, B. C., Johnson, G., Heath, O., Mcmanamon, P. J., O'Leary, E. and Pryse-Phillips, W. (1989). The Cardinal Manifestations of Bardet-Biedl Syndrome, a Form of Laurence-Moon-Biedl Syndrome. New England Journal of Medicine 321, 1002-1009.

Grudzinska Pechhacker, M. K., Jacobson, S. G., Drack, A. V., Scipio, M. D., Strubbe, I., Pfeifer, W., Duncan, J. L., Dollfus, H., Goetz, N., Muller, J., et al. (2021). Comparative Natural History of Visual Function From Patients With Biallelic Variants in BBS1 and BBS10. Investigative Opthalmology \& Visual Science 62, 26.

Hsu, Y., Garrison, J. E., Kim, G., Schmitz, A. R., Searby, C. C., Zhang, Q., Datta, P., Nishimura, D. Y., Seo, S. and Sheffield, V. C. (2017). BBSome function is required for both the morphogenesis and maintenance of the photoreceptor outer segment. PLoS genetics 13, e1007057-e1007057.

Laird, J. G., Gardner, S. H., Kopel, A. J., Kerov, V., Lee, A. and Baker, S. A. (2019). Rescue of Rod Synapses by Induction of Cav Alpha 1F in the Mature Cav1.4 Knock-Out Mouse Retina. Investigative Opthalmology \& Visual Science 60, 3150.

Lujan, B. J., Roorda, A., Croskrey, J. A., Dubis, A. M., Cooper, R. F., Bayabo, J.-K., Duncan, J. L., Antony, B. J. and Carroll, J. (2015). DIRECTIONAL OPTICAL COHERENCE TOMOGRAPHY PROVIDES ACCURATE OUTER NUCLEAR LAYER AND HENLE FIBER LAYER MEASUREMENTS. Retina 35, 1511-1520.

Mardy, A. H., Hodoglugil, U., Yip, T. and Slavotinek, A. M. (2021). Third case of BardetBiedl syndrome caused by a biallelic variant predicted to affect splicing of IFT74. Clinical Genetics 100, 93-99.

Mcculloch, D. L., Marmor, M. F., Brigell, M. G., Hamilton, R., Holder, G. E., Tzekov, R. and Bach, M. (2015). ISCEV Standard for full-field clinical electroretinography (2015 update). Documenta Ophthalmologica 130, 1-12.

Morris, R. (1984). Developments of a water-maze procedure for studying spatial learning in the rat. Journal of Neuroscience Methods 11, 47-60.

Mykytyn, K., Nishimura, D. Y., Searby, C. C., Shastri, M., Yen, H.-J., Beck, J. S., Braun, T., Streb, L. M., Cornier, A. S., Cox, G. F., et al. (2002). Identification of the gene (BBS1) most commonly involved in Bardet-Biedl syndrome, a complex human obesity syndrome. Nature Genetics 31, 435-438.

Nishimura, D. Y., Fath, M., Mullins, R. F., Searby, C., Andrews, M., Davis, R., Andorf, J. L., Mykytyn, K., Swiderski, R. E., Yang, B., et al. (2004). Bbs2-null mice have neurosensory deficits, a defect in social dominance, and retinopathy associated with mislocalization of rhodopsin. Proceedings of the National Academy of Sciences 101, 16588-16593.

Pang, J.-J., Boye, S. L., Kumar, A., Dinculescu, A., Deng, W., Li, J., Li, Q., Rani, A., Foster, T. C., Chang, B., et al. (2008). AAV-Mediated Gene Therapy for Retinal Degeneration in the rd10 Mouse Containing a Recessive PDE $\beta$ Mutation. Investigative Opthalmology \& Visual Science 49, 4278. 
Pang, J.-j., Chang, B., Kumar, A., Nusinowitz, S., Noorwez, S. M., Li, J., Rani, A., Foster, T. C., Chiodo, V. A., Doyle, T., et al. (2006). Gene Therapy Restores Vision-Dependent Behavior as Well as Retinal Structure and Function in a Mouse Model of RPE65 Leber Congenital Amaurosis. Molecular Therapy 13, 565-572.

Prusky, G. T., West, P. W. R. and Douglas, R. M. (2000). Behavioral assessment of visual acuity in mice and rats. Vision Research 40, 2201-2209.

Robson, A. G., Nilsson, J., Li, S., Jalali, S., Fulton, A. B., Tormene, A. P., Holder, G. E. and Brodie, S. E. (2018). ISCEV guide to visual electrodiagnostic procedures. Documenta Ophthalmologica 136, 1-26.

Sarria, I., Pahlberg, J., Cao, Y., Kolesnikov, A. V., Kefalov, V. J., Sampath, A. P. and Martemyanov, K. A. (2015). Sensitivity and kinetics of signal transmission at the first visual synapse differentially impact visually-guided behavior. eLife $\mathbf{4}$.

Schachat, A. P. and Maumenee, I. H. (1982). Bardet-Biedl Syndrome and Related Disorders. Archives of Ophthalmology 100, 285-288.

Singh, S. K., Gui, M., Koh, F., Yip, M. C. and Brown, A. (2020). Structure and activation mechanism of the BBSome membrane protein trafficking complex. eLife $\mathbf{9}$.

Stoetzel, C., Laurier, V., Davis, E. E., Muller, J., Rix, S., Badano, J. L., Leitch, C. C., Salem, N., Chouery, E., Corbani, S., et al. (2006). BBS10 encodes a vertebrate-specific chaperonin-like protein and is a major BBS locus. Nature Genetics 38, 521-524.

Tanimoto, N., Sothilingam, V., Kondo, M., Biel, M., Humphries, P. and Seeliger, M. W. (2015). Electroretinographic assessment of rod- and cone-mediated bipolar cell pathways using flicker stimuli in mice. Scientific Reports 5, 10731.

Weihbrecht, K., Goar, W. A., Pak, T., Garrison, J. E., DeLuca, A. P., Stone, E. M., Scheetz, T. E. and Sheffield, V. C. (2017). Keeping an Eye on Bardet-Biedl Syndrome: A Comprehensive Review of the Role of Bardet-Biedl Syndrome Genes in the Eye. Medical research archives 5, 10.18103/mra.v18105i18109.11526.

Zhang, Q., Nishimura, D., Seo, S., Vogel, T., Morgan, D. A., Searby, C., Bugge, K., Stone, E. M., Rahmouni, K. and Sheffield, V. C. (2011). Bardet-Biedl syndrome 3 (Bbs3) knockout mouse model reveals common BBS-associated phenotypes and Bbs3 unique phenotypes. Proceedings of the National Academy of Sciences 108, 20678-20683.

Zhang, Q., Nishimura, D., Vogel, T., Shao, J., Swiderski, R., Yin, T., Searby, C., Carter, C. C., Kim, G., Bugge, K., et al. (2013). BBS7 is required for BBSome formation and its absence in mice results in Bardet-Biedl syndrome phenotypes and selective abnormalities in membrane protein trafficking. Journal of Cell Science 126, 2372-2380.

Zhou, Z., Qiu, H., Castro-Araya, R.-F., Takei, R., Nakayama, K. and Katoh, Y. (2021). Impaired cooperation between IFT74/BBS22-IFT81 and IFT25-IFT27/BBS19 causes Bardet-Biedl syndrome. Human Molecular Genetics.

Acknowledgements: We thank L.L. Wallrath for edits to the manuscript. This research was supported by grants from Fighting Blindness Canada, The Bardet Biedl Syndrome Family Association, Ronald Keech Professorship, and University of lowa Institute for Vision Research. This research was supported in part by an NIH/NEI Center Support Grant to the University of lowa (P30 EY025580).

Author contributions:

Manuscript writing and figure preparation: S.K.M., J.T., Y.H. and A.V.D. 
Data Acquisition: S.K.M., J.T., M.H., A.K., I.C., A.S., E.S., P.D., C.S., Y.H., S.B. Materials provided: C.S., S.S., V.C.S.

Study concept and design: S.S., V.C.S., A.V.D.

Statistical analysis: S.K.M., K.W.

Additional Information/Competing Interests: NA

Figure Legends:

Figure 1: $\mathrm{Bbs} 10^{-/}$mice have altered weight relative to controls.

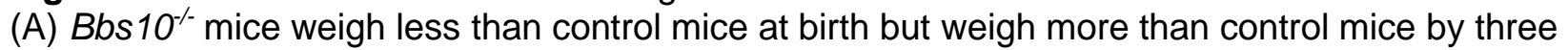
months of age. Representative mice at one and 7 months of age are shown for each genotype. Note the smaller size of the $\mathrm{Bb}_{10} \mathrm{\sigma}^{-/}$mouse at one month of age and the slightly thinner abdomen of the control mouse at seven months of age. (B) Comparisons between the two mouse groups from P19 to four months of age are shown. The weights are statistically different at ages 3 and 4 months while age P19-P21 is not but this could be due to small weights and sample size. A 2way ANOVA Šídák's multiple comparisons test was performed between the means of each age group of control and affected mice. ${ }^{* *}=p$-value $<0.01,{ }^{* * *}=p$-value $<0.001$

Figure 2: $B b s 10^{-/}$mice exhibited a progressively thinner outer nuclear layer compared to controls. (A) Optical Coherence Tomography (OCT) images of control and $\mathrm{Bbs} 10^{-/}$mice from $\mathrm{P} 19$ to 8 months are shown. The $B s 10^{-/}$mice exhibit a degenerating outer nuclear layer (ONL) while controls remain stable over time. (B) The graph depicts the ONL thickness of control mice and $\mathrm{Bbs}_{10^{--}}$mice at different ages. The $\mathrm{Bbs} 10^{--} \mathrm{ONL}$ was initially less than that of controls and decreased with age, until it was non-detectable at seven months of age. A 2-way ANOVA Šídák's multiple comparisons test was performed between the means of each age group of control and affected mice. ${ }^{* *}=p$-value $<0.01,{ }^{* * * *}=p$-value $<0.0001$

Figure 3: Bbs 10/- mice display disorganized photoreceptor outer segments at P15. Comparison of a control mouse retina with $B b s 10^{-\%}$ mouse retina under transmission electron microscopy. The large outer segment discs of the control mouse (arrow) are highly organized while the corresponding outer segments in the $\mathrm{Bbs}_{10^{-/}}$mouse are disorganized.

Figure 4: $B b s 10^{-/}$mice have abnormal cone protein localization compared to controls. OPN1MW and GNAT2 are cone specific proteins that are abnormal in Bbs $10^{-/}$retinas at P21. Control mice display prominent protein staining (green) for both cone-specific proteins. Bbs $10^{-1-}$ mice display staining for OPN1MW; however, it is mislocalized to the inner segments. Staining GNAT2 was nearly undetectable in mutant mice.

Figure 5: $B b s 10^{-/}$mice have abnormal electroretinograms (ERG) compared to those of control mice. (A) Overlay of a representative control and $B b s 10^{-/}$mouse ERG waveforms under the $0.01 \mathrm{~cd} \cdot \mathrm{s} / \mathrm{m}^{2}$ dark adapted dim flash condition at one month and six months of age. Bbs $10^{-/}$ mice exhibit rod generated b-waves that are recordable but consistently possess a lower amplitude than those of control mice over the course of their lifespan. (B) Overlays of representative control and $B b s 10^{-/-}$mouse ERG waveforms under the $3.0 \mathrm{~cd} \cdot \mathrm{s} / \mathrm{m}^{2}$ dark adapted standard combined response (SCR) at one and six months of age. Bbs $10^{-/}$mice exhibit bwaves with lower amplitudes when compared to those of control mice and this difference continues over the lifespan of the mouse. (C) Overlay of representative control and $\mathrm{Bbs} 10^{-/}$ mouse ERG waveforms under the light adapted $3.0 \mathrm{~cd} \cdot \mathrm{s} / \mathrm{m}^{2}$ bright flash. The $\mathrm{Bbs} 10^{-/}$mice 
exhibit a miniscule response at one month of age and is completely absent at six months of age. This difference is prominent throughout the lifespan of the mice. (D) The light adapted $5 \mathrm{~Hz}$ flicker ERG response of control and $\mathrm{Bbs}^{-/ /}$mice at one month of age and six months of age is shown. The response is unrecordable by one month of age in $B b s 10^{-/}$mice, which was the earliest time point tested. Quantification of the waveforms was not performed due to the lack of signal beyond background. A 2-way ANOVA Šídák's multiple comparisons test was performed between the means of each age group of control and affected mice. ${ }^{* * *}=p$-value $<0.0001$

Figure 6: $B b s 10^{-/}$mice have reduced functional vision compared to that of control mice. The visually guided swim assay is a test of functional vision in mice and is measured by time to platform (TTP). Longer TTP suggests reduced functional vision. Bbs10/- mice have longer TTP at six months of age in light adapted and dark adapted conditions when compared to control mice. This difference remains as the mice age to nine months. Unpaired T-tests were performed to determine statistical differences between control and $B b s 10^{-/}$mice at different ages and light conditions. ${ }^{*}=p$-value $<0.05,{ }^{* * * *}=p$-value $<0.0001$

Figure 7: $B b s 10^{-/}$mice have a more severe retinal degeneration phenotype than that of a BBS1 mouse model, Bbs $1^{\text {M390R/M390R }}$. (A) OCT images of six months old Bbs $1^{\text {M390R/M390R }}$ mice and $B b s 10^{-1-}$ mice show differences in ONL thickness. The Bbs $1^{M 390 R / M 390 R}$ mouse had a thin but present ONL while the Bbs $10^{-/}$mouse lacked any observable ONL. (B) ERG waveform overlays of the four ERG conditions previously described (Fig. 5) between $B b s 1^{M 390 R / M 39 R}$ and $B b s 10^{-/-}$at six months of age are shown. Bbs $10^{-/}$mice have lower waveforms than $B b s 1^{M 390 R / M 390 R}$ mice in all four conditions. Bbs $1^{M 390 R / M 390 R}$ mice have a detectable $5 \mathrm{~Hz}$ flicker response at six months while the $B b s 10^{-1}$ lack this response from at least one month of age onward. (C) Bbs $1^{\text {M390R/M390R }}$ mice exhibit better functional vision compared to that of $B b s 10^{-/}$mice at six months of age in the

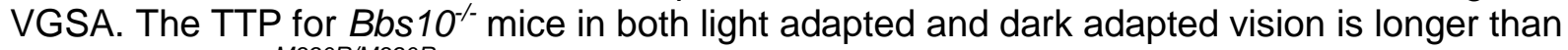
that of the $B b s 1^{\text {M390R/M390R }}$ mice tested under the same conditions. Unpaired T-tests were performed to determine statistical differences between $B b s 1^{M 390 R / M 390}$ and $B b s 10^{-/}$mice at different ages and light conditions. ${ }^{*}=p$-value $<0.05,{ }^{* *}=p$-value $<0.01$

Figure S1: Bbs10--- mice have no Bbs10 mRNA present. The figure displays RT-PCR results demonstrating that $\mathrm{Bbs} 10^{-/-}$do not produce any mRNA that can be detected. Actin was used as a control, which shows robust expression data in all mice.

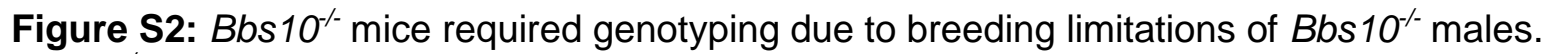
$B b s 10^{-/}$mice have a deletion of both exons of the Bbs10 gene and thus have a smaller PCR product upon genotyping that created bands located at 445bp for the WT band and 260bp for the knockout band. Two appropriately sized products are present in heterozygous mice.

Figure S3S3: $\mathrm{Bbs}_{10} \mathrm{O}^{-}$mice have a thinner outer nuclear layer (ONL) compared to control mice. Control mice have a constant thickness of the ONL throughout their lifespan. Differences in apparent thickness in control images is due to sectioning techniques that spreads out the cell layers. In contrasts, the ONL layer of $B b s 10^{-/}$mice become progressively thinner over the mouse lifespan and show only a single-cell layer by seven months of age. 
Figure 1

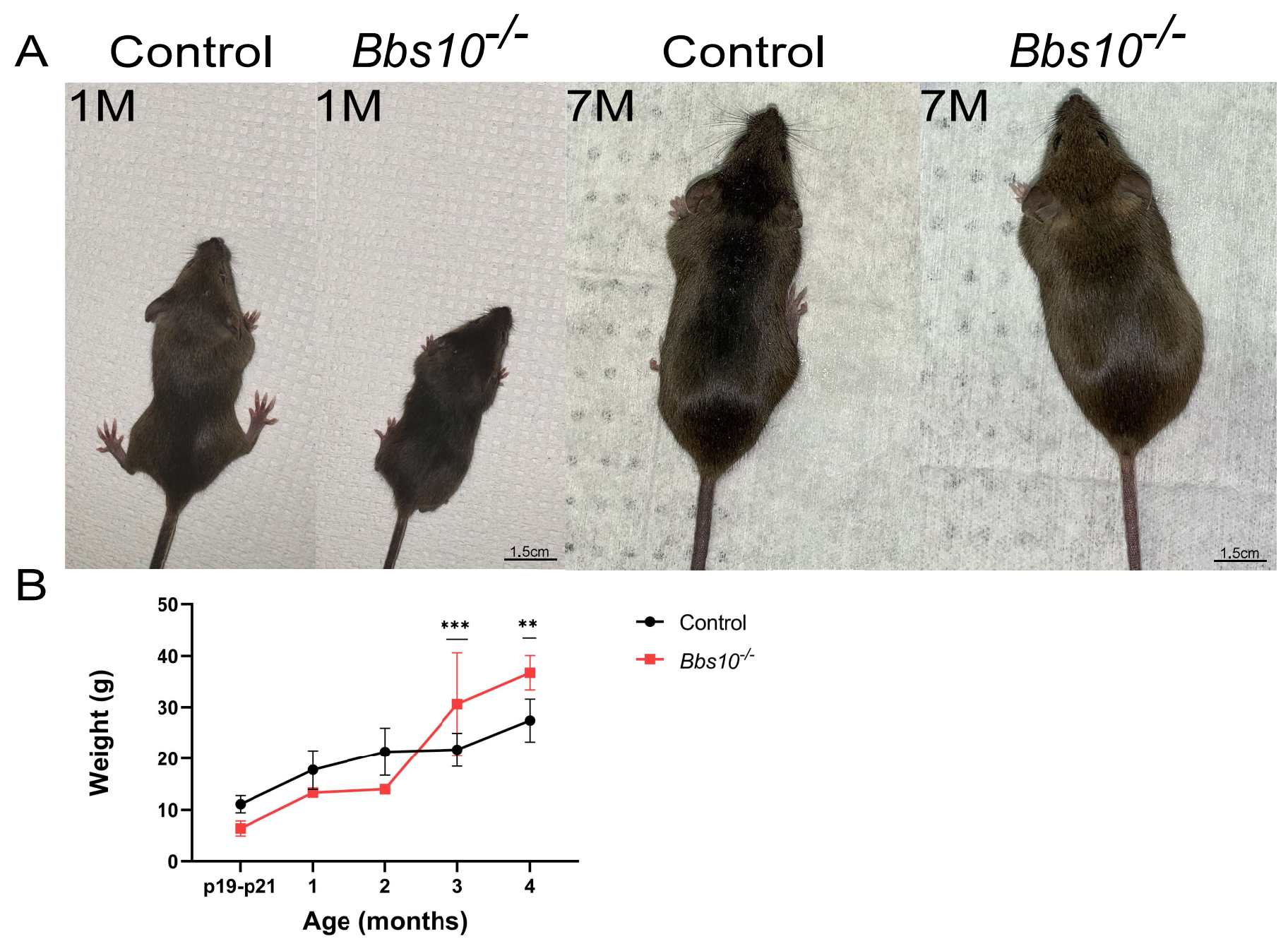


Figure 2

\section{A Control Bbs10 ${ }^{-1-}$ B}

3 Months

p19

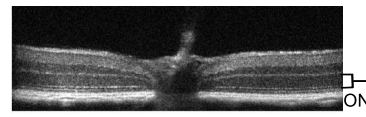

1 Month
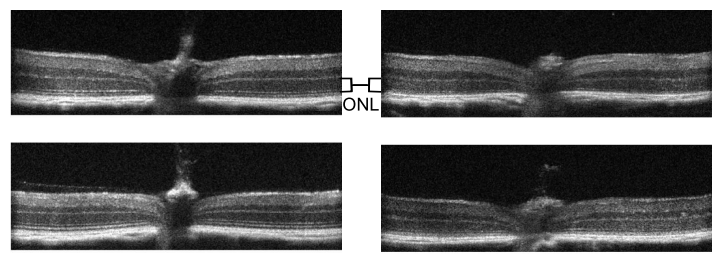

2 Months
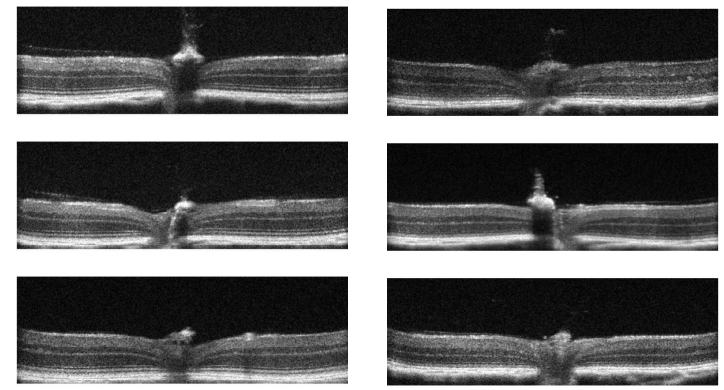

4 Months

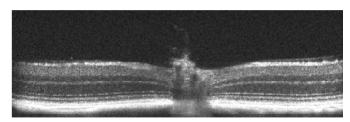

5 Months
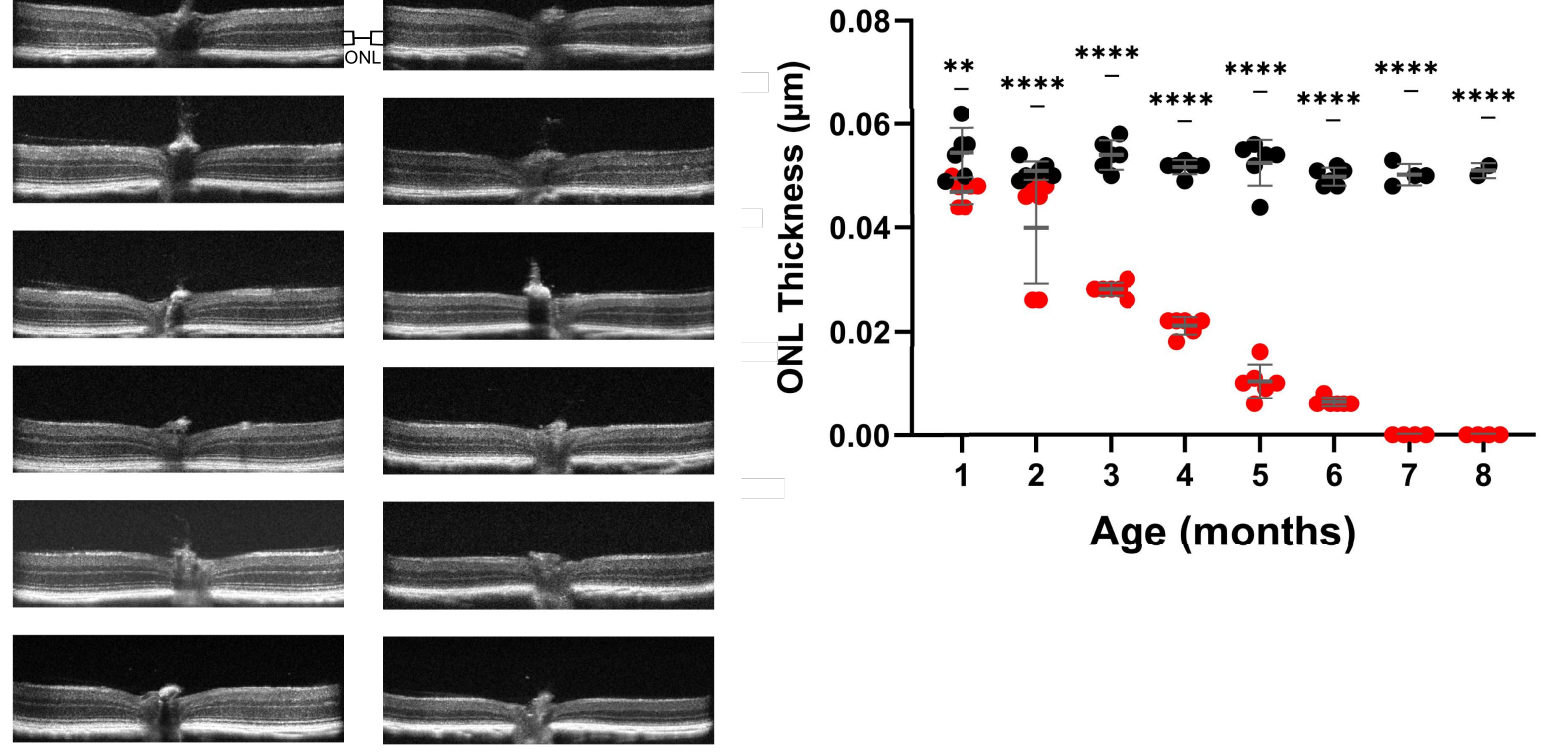

6 Months
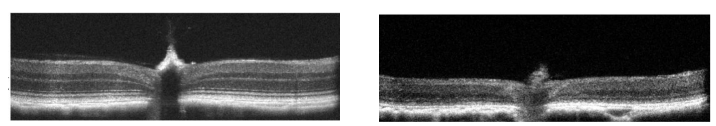

7 Months
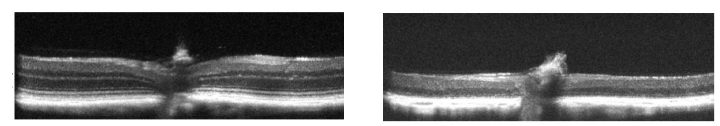

8 Months
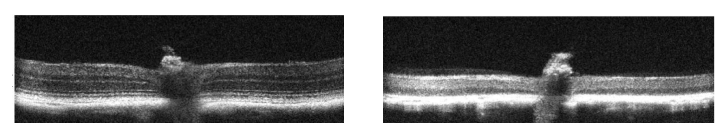

- Control

- $B b s 10^{-/-}$ 
bioRxiv preprint doi: https://doi.org/10.1101/2022.01.19.476952; this version posted January 21, 2022. The copyright holder for this preprint (which was not certified by peer review) is the author/funder, who has granted bio Rxiv a license to display the preprint in perpetuity. It is made

Figure 3
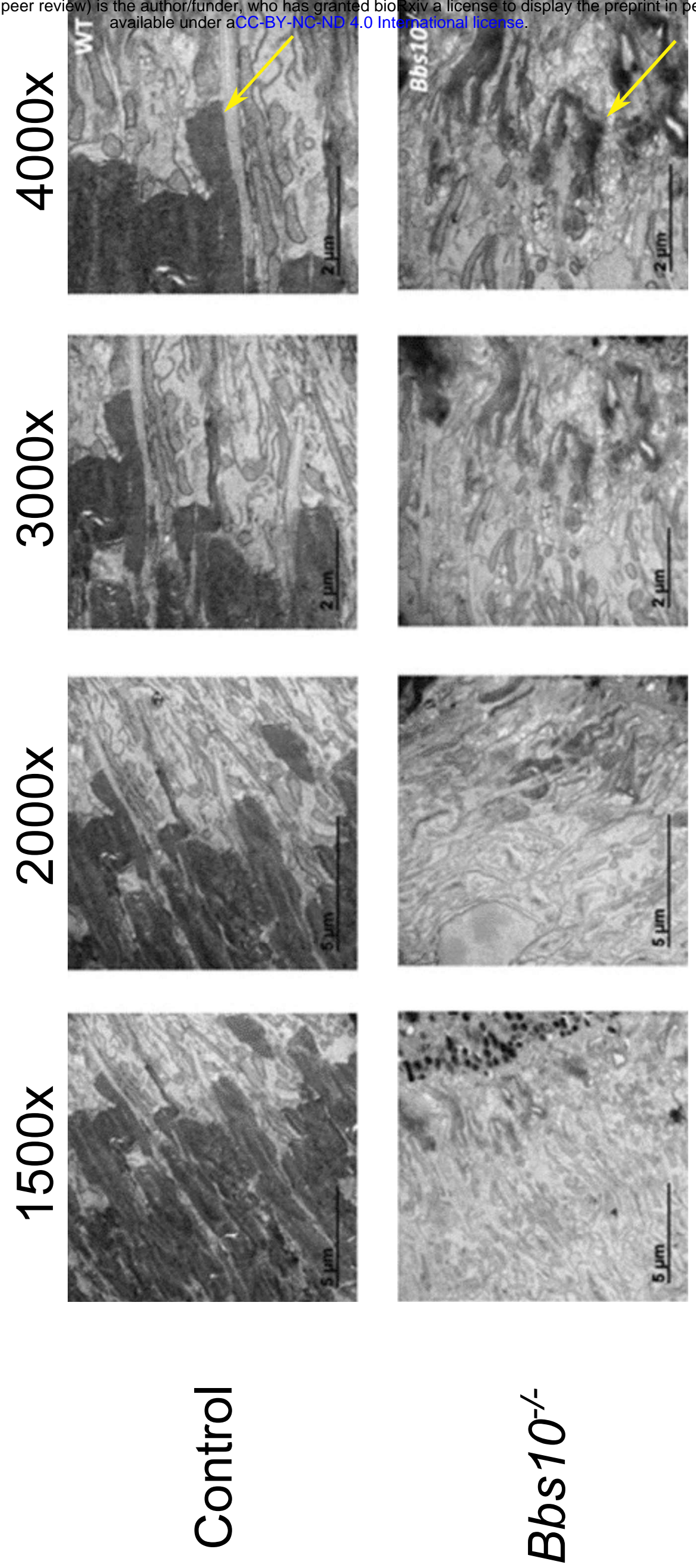
bioRxiv preprint doi: https://doi.org/10.1101/2022.01.19.476952; this version posted January 21, 2022. The copyright holder for this preprint (which was not certified by peer review) is the author/funder, who has granted bioRxiv a license to display the preprint in perpetuity. It is made available under aCC-BY-NC-ND 4.0 International license.

Figure 4

\section{Control}

OPN1MW

DAPI

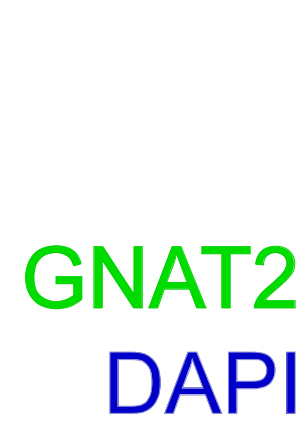

Bbs10--

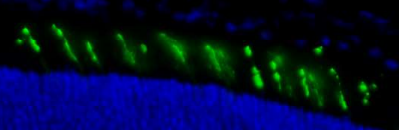

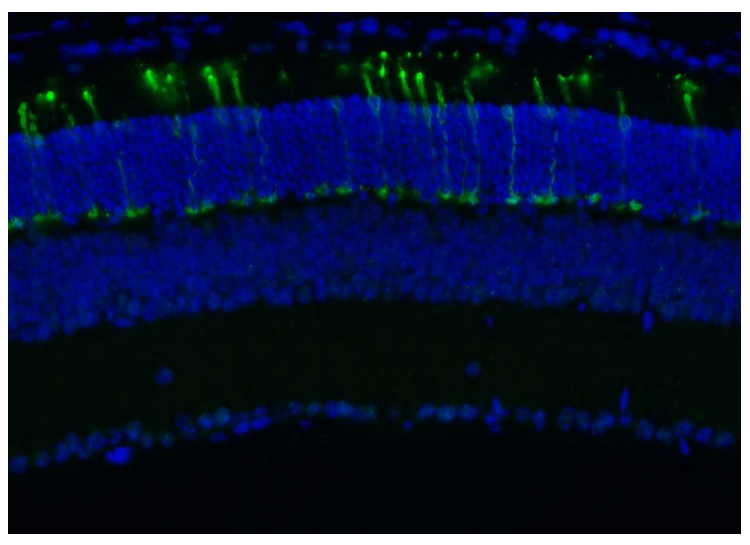
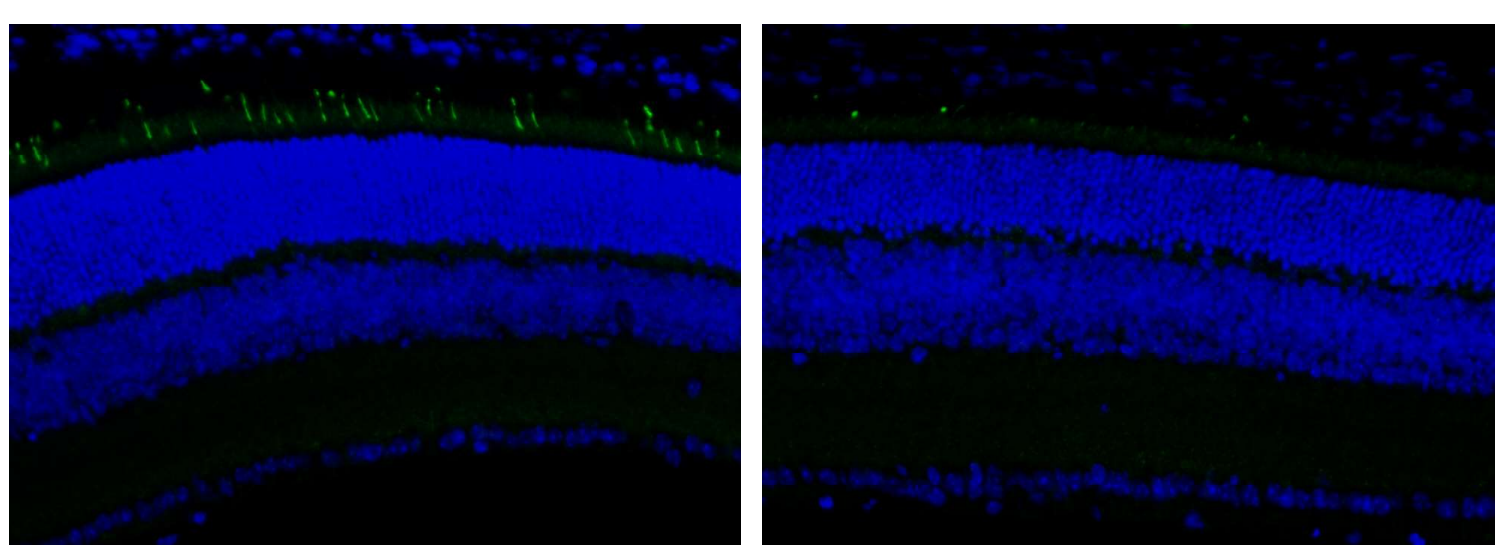
bioRxiv preprint doi: https://doi.org/10.1101/2022.01.19.476952; this version posted January 21, 2022. The copyright holder for this preprint (which was not certified by peer review) is the author/funder, who has granted bioRxiv a license to display the preprint in perpetuity. It is made available under aCC-BY-NC-ND 4.0 International license.

Figure 5

1 Month Old 6 Months Old

A

B

\subsection{Dim Flash}
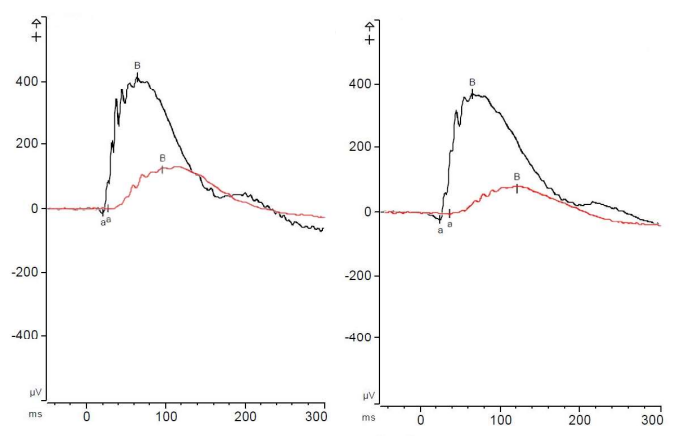

C

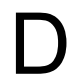

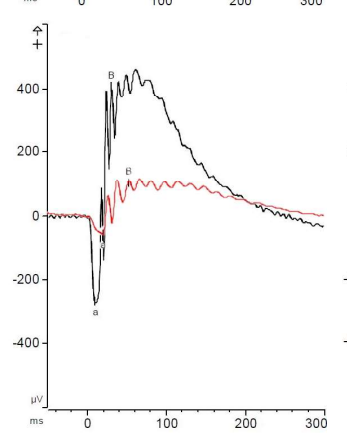
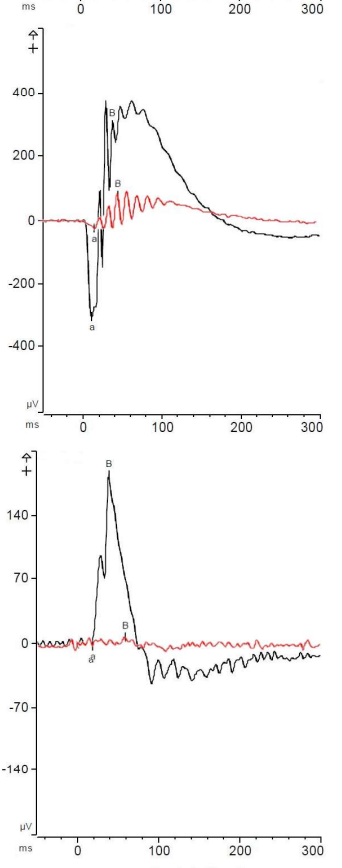

3.0 Flash
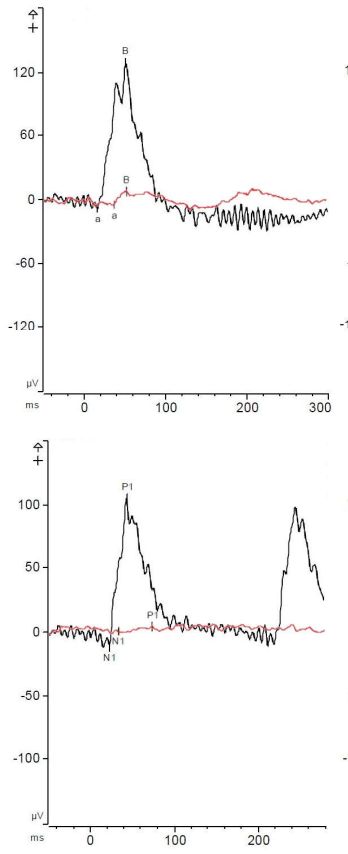

$5 \mathrm{~Hz}$ Flicker

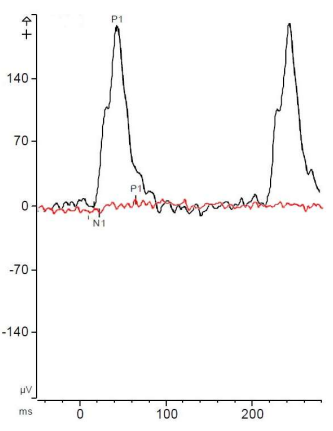

b-wave over time
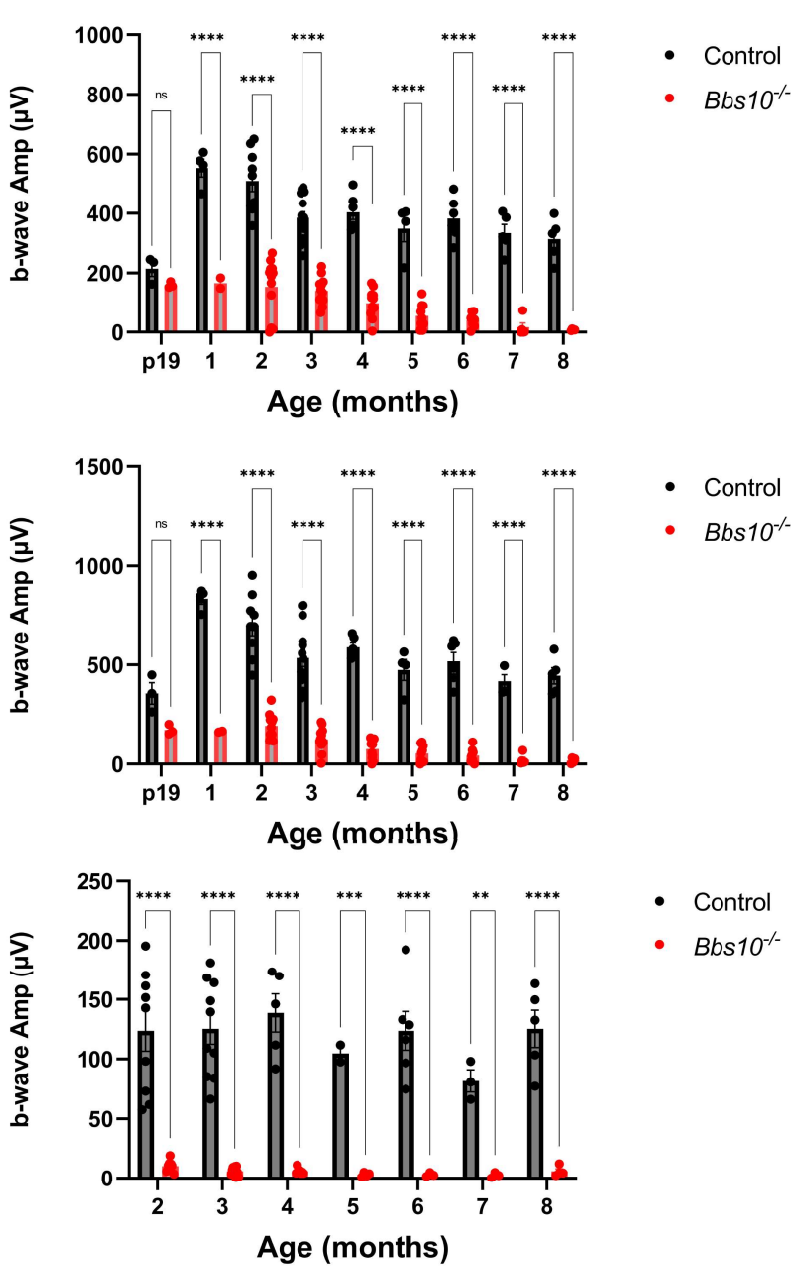


\section{Months Old}

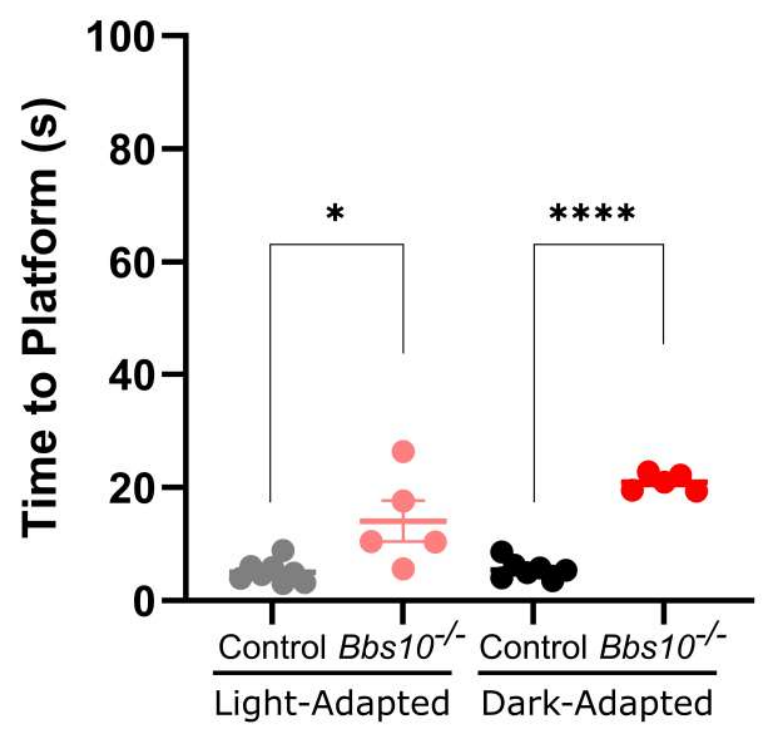

9 Months Old

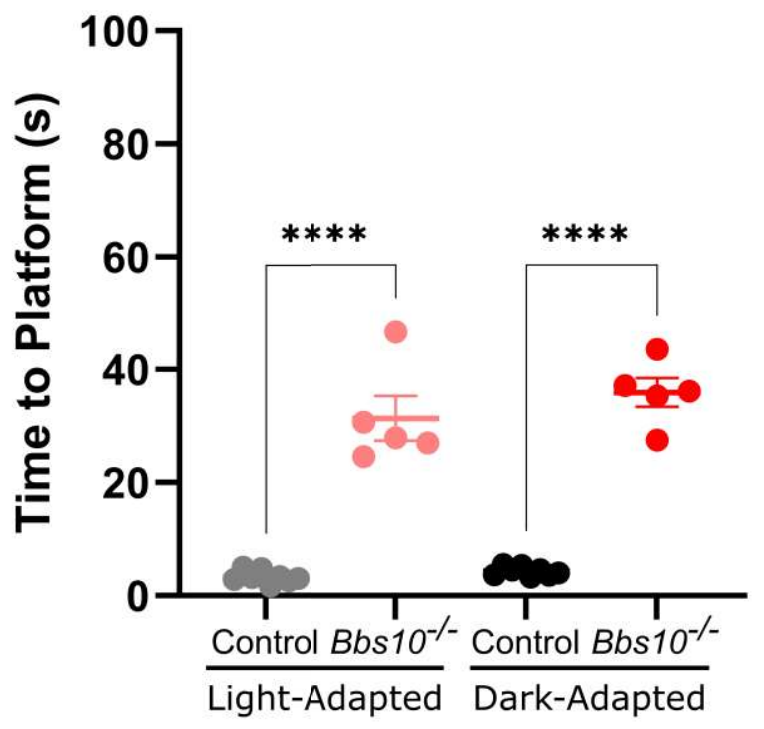


bioRxiv preprint doi: https://doi.org/10.1101/2022.01.19.476952; this version posted January 21, 2022. The copyright holder for this preprint (which was not certified by peer review) is the author/funder, who has granted bioRxiv a license to display the preprint in perpetuity. It is made

\section{Figure 7} available under aCC-BY-NC-ND 4.0 International license.

bioRxiv preprint doi: https://doi.org/10.1101/2022.01.19.476952; this version posted January 21, 2022. The copyright holder for this preprint (which was not certified by peer review) is the author/funder, who has granted bioRxiv a license to display the preprint in perpetuity. It is made available under aCC-BY-NC-ND 4.0 International license.

Figure S1

Beta-Actin cDNA

Water

Blank Bbs10 $10^{+-} \mathrm{Bbs} 10^{+/-} \mathrm{Bbs} 10^{-/-}$Bbs $10^{-/-}$Blank
Bbs10 cDNA

Water

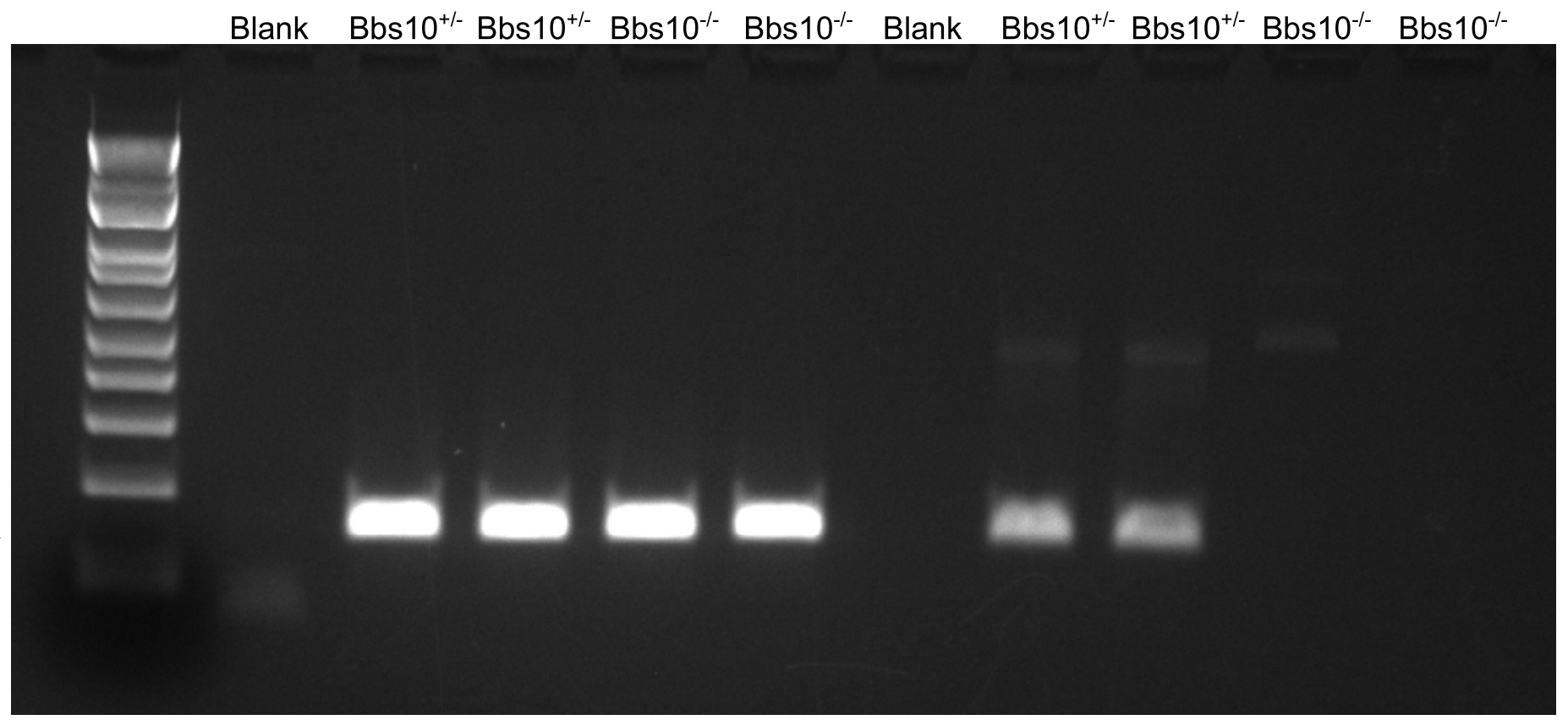


bioRxiv preprint doi: https://doi.org/10.1101/2022.01.19.476952; this version posted January 21, 2022. The copyright holder for this preprint (which was not certified by peer review) is the author/funder, who has granted bioRxiv a license to display the preprint in perpetuity. It is made available under aCC-BY-NC-ND 4.0 International license.

Figure S2

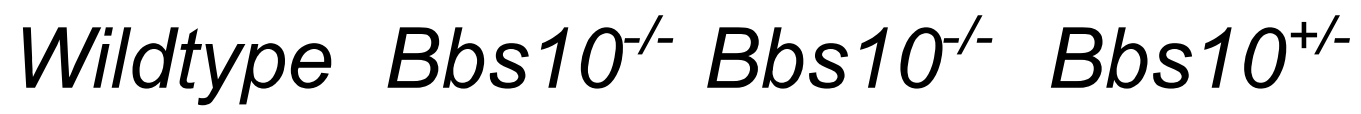

WT band $445 \mathrm{bp}$ $\mathrm{KO}$ band $300 \mathrm{bp}$
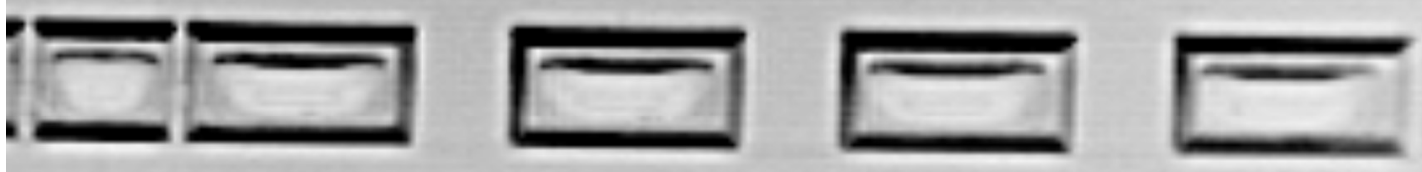
bioRxiv preprint doi: https://doi.org/10.1101/2022.01.19.476952; this version posted January 21, 2022. The copyright holder for this preprint (which was not certified by peer review) is the author/funder, who has granted bioRxiv a license to display the preprint in perpetuity. It is made available under aCC-BY-NC-ND 4.0 International license.

Figure S3
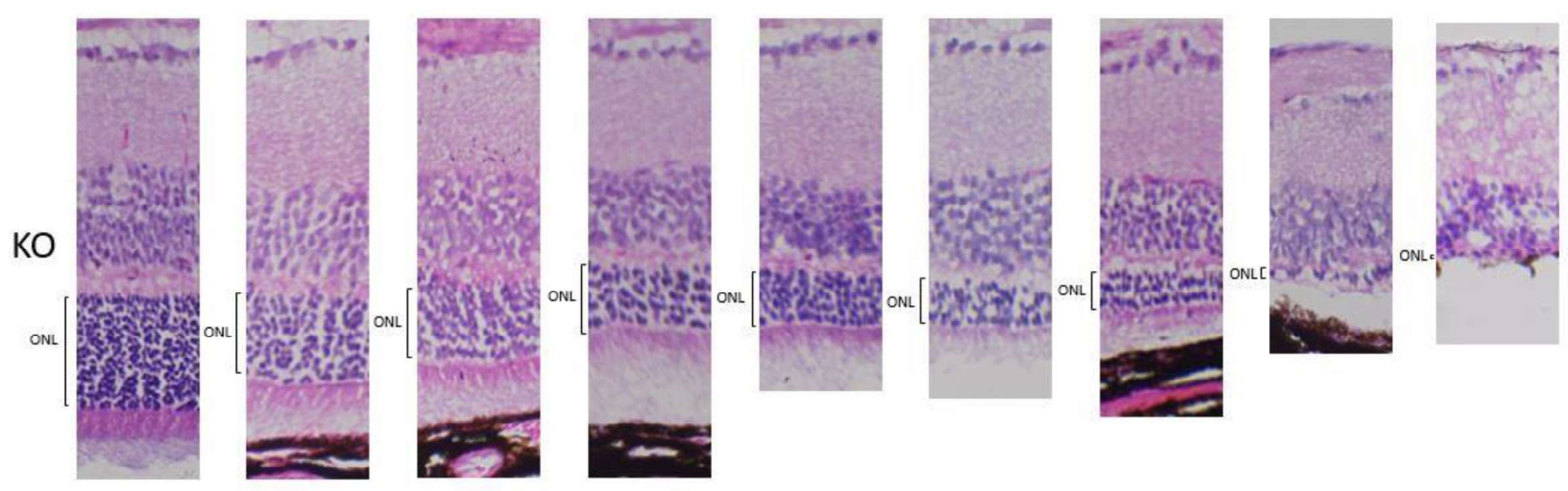

19 days old

1 month old

2 months old

3 months old

4 months old

5 months old

6 months old

7 months old

8 months old
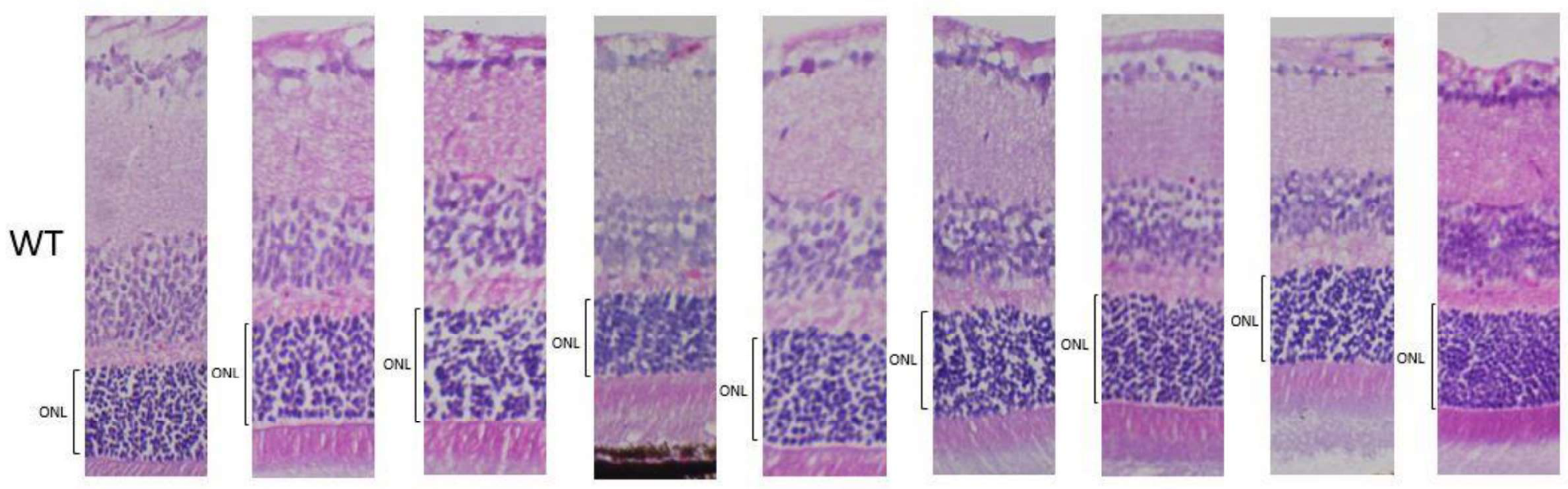
bioRxiv preprint doi: https://doi.org/10.1101/2022.01.19.476952; this version posted January 21, 2022. The copyright holder for this preprint (which was not certified by peer review) is the author/funder, who has granted bioRxiv a license to display the preprint in perpetuity. It is made available under aCC-BY-NC-ND 4.0 International license.

\begin{tabular}{|c|c|c|c|}
\hline Gene Name & Primer Sequence & Experiment & Product Size \\
\hline mBact-qF & 5' - TCGAGTCGCGTCCACC - 3' & RT-PCR & \\
\hline mBact-qR & 5' - GGGAGCATCGTCGCCC - 3' & RT-PCR & $157 \mathrm{bp}$ \\
\hline mBbs10-RT-F & 5' - TGCTTAGCAGGGATGGAG - 3' & RT-PCR & \\
\hline mBbs10-RT-R & 5' - TCCTCTGAGTAAATGGCAAAGA - 3' & RT-PCR & $152 \mathrm{bp}$ \\
\hline mBbs10KO-WT-Fr & 5' - CCCATGGTAAGTGGTCAATCAG - 3' & Genotypying PCR & $445 \mathrm{bp}$ \\
\hline mBbs10KO-Mt-Fr & 5' - TCAATGTATCTTATCATGTCTG - 3' & Genotypying PCR & $260 \mathrm{bp}$ \\
\hline mBbs10KO-Rv & 5' - TGGTCTGGTGGACTCAATGGAC - 3' & Genotypying PCR & \\
\hline
\end{tabular}


bioRxiv preprint doi: https://doi.org/10.1101/2022.01.19.476952; this version posted January 21, 2022. The copyright holder for this preprint (which was not certified by peer review) is the author/funder, who has granted bioRxiv a license to display the preprint in perpetuity. It is made available under aCC-BY-NC-ND 4.0 International license.

\section{Notes}

With Reverse (Rv) mBbs10KO

With Reverse (Rv) mBbs10KO 